\title{
PEMBUATAN PESTISIDA NABATI UNTUK MENGENDALIKAN HAMA DAN PENYAKIT PADA TANAMAN SAYURAN DI DISTRIK SIEPKOSI KABUPATEN JAYAWIJAYA
}

\author{
Sumiyati Tuhuteru ${ }^{1 *}$, Anti U. Mahanani ${ }^{1}$, Rein E. Y. Rumbiak ${ }^{2}$ \\ ${ }^{1}$ Program Studi Agroteknologi, Sekolah Tinggi Ilmu Pertanian Petra Baliem, Wamena, Indonesia \\ ${ }^{2}$ Program Studi Agribisnis, Sekolah Tinggi Ilmu Pertanian Petra Baliem, Wamena, Indonesia \\ *Penulis Korespondensi: tuhuteru.umy@gmail.com
}

\begin{abstract}
Abstrak
Wamena sebagai salah satu sentra pertanian organik di wilayah Indonesia Timur yang memiliki potensi yang cukup besar dalam pengembangan sektor pertanian, khususnya pengembangan tanaman pangan dan hortikultura. Seiring dengan itu, saat ini telah meningkat dengan pesat pola pertanian organik mulai menjadi idola dalam dunia pertanian. Produk pertanian yang selama ini menggunakan pupuk kimia dan pestisida non-organik mulai tergantikan dengan produk pertanian organik yang memanfaatkan bahan alami, sebagai pupuk maupun pestisida. Salah satu faktor penghambat dalam budi daya tanaman adalah serangan hama dan patogen. Pengendalian hama dan patogen di Wamena sejauh ini tidak dilakukan dengan sebagaimana mestinya bahkan dikatakan tradisional, seperti hanya melalui pengasapan disekitar tanaman yang dibudidaya. Tujuan dari kegiatan pengabdian ini adalah meningkatkan pengetahuan dan keterampilan petani di Desa Isaba Himan, Distrik Siepkosi, Kota Wamena, Kabupaten Jayawijaya dalam membuat dan mengaplikasikan pestisida nabati (pestisida alami) untuk mengendalikan hama dan patogen pada tanaman yang dibudidayakan. Pelaksanaan kegiatan melalui KKN-PPM ini adalah dengan memberikan sosialisasi serta pelatihan pembuatan pestisida nabati dengan bahan-bahan yang ada dilingkungan sekitar. Hasil pengabdian masyarakat ini adalah masyarakat di Distrik Siepkosi dapat mengembangkan pengetahuan terkait pestisida nabati guna membantu meningkatkan produktivitas tanaman, sehingga masyarakat dapat meningkatkan sistem pertanian organik yang telah ada.
\end{abstract}

Kata Kunci: Pestisida Nabati, Pupuk Organik Cair, Pertanian Organik, Wamena, Papua.

\begin{abstract}
Wamena as one of the centers of organic agriculture in Eastern Indonesia which has considerable potential in the development of the agricultural sector, especially the development of food crops and horticulture. Along with that, nowadays has increased rapidly the pattern of organic farming began to become an idol in the world of agriculture. Agricultural products that have been using chemical fertilizers and non-organic pesticides have begun to be replaced with organic agricultural products that utilize natural ingredients, like fertilizers and pesticides. One inhibiting factor in plant cultivation is the attack of pests and pathogens. So far, the control of pests and pathogens in Wamena is not done properly as it is even said to be traditional, such as only through fumigation around cultivated plants. The purpose of this community service activity is to improve the knowledge and skills of farmers in Isaba Himan Village, Siepkosi District, Wamena City, Jayawijaya Regency in making and applying plant-based pesticides (natural pesticides) to control pests and pathogens in cultivated plants. The implementation of activities through KKN-PPM is to provide socialization and training in making botanical pesticides with materials in the surrounding environment. The result of this community service is that people in Siepkosi District can develop knowledge related to botanical pesticides to increase crop productivity so that the community can improve existing organic farming systems.
\end{abstract}

Keywords: Botanical Pesticides, Liquid Organic Fertilizers, Organic Agriculture, Wamena, Papua. 


\section{PENDAhuluan}

Salah satu sektor yang berpotensi dalam meningkatkan ketahanan pangan adalah sektor pertanian. Sektor pertanian memiliki kontribusi yang sangat nyata dalam perekonomian nasional melalui pembentukan PDB, sumber devisa melalui ekspor, penyediaan pangan dan penyediaan bahan baku industri, pengentasan kemiskinan, penyedia lapangan kerja dan pendapatan masyarakat. Selain kontribusi langsung, sektor pertanian juga memiliki kontribusi yang tidak langsung berupa efek pengganda (multiple effect) berupa keterkaitan input-output antar industri, konsumsi dan investasi. Dampak pengganda tersebut relatif besar sehingga sektor pertanian layak dijadikan sektor andalan dalam pembangunan ekonomi nasional. Namun, salah satu masalah yang sering dihadapi oleh para petani, terutama petani sayuran di Wamena adalah serangan hama, baik berupa nematoda, ulat, lalat buah maupun antraknosa. Serangan hama ini seringkali menggagalkan panen sehingga menyebabkan kerugian yang sangat besar. Untuk itu, peningkatan produksi tanaman merupakan salah tujuan dalam program pertanian. Agar tanaman tidak dirusak oleh hama dan penyakit salah satu upaya yang dilakukan adalah dengan menggunakan pestisida (Ningrum et al., 2014).

Melihat kontur dan dan kondisi alam di daerah timur Indonesia, dapat dikatakan bahwa Papua adalah masa depan pertanian Indonesia, karena luas lahannya begitu luas dan penduduknya masih sedikit, terutama daerah pegunungan tengah. Papua layak dikembangkan sebagai sentra pertanian organik Indonesia bagian timur. Hal ini terkait dengan sistem budidaya yang diterapkan petani setempat adalah sistem tanam ladang berpindah, dan penerapan prinsip-prinsip LEISA (Low External Input Suistenable Agriculture). Petani tidak menggunakan pupuk anorganik bahkan pestisida untuk mengendalikan hama penyakit. Untuk itu, penggunaan pestisida pada tanaman sayuran di dataran tinggi tergolong sangat intensif, hal ini terutama disebabkan kondisi iklim yang sejuk dengan kelembaban udara dan curah hujan yang tinggi menciptakan kondisi yang baik untuk perkembangbiakan hama dan penyakit tanaman. Namun apabila penggunaan pestisida yang tidak tepat baik secara jenis, waktu, dosis, cara, dan sasaran akan menimbulkan pencemaran dan berdampak pada kesehatan (Munarso et al., 2006).

Sektor pertanian organik di Provinsi Papua, terutama di wilayah Pegunungan Tengah seperti Wamena dan sekitarnya sampai saat ini belum dapat dibenahi sebagaimana pertanian berkelanjutan yang diharapkan. Proses budidaya yang dilakukan petani di wilayah Wamena dan sekitar masih terbilang terikat oleh budaya setempat. Sehingga, belum dapat diselaraskan dengan yang semestinya. Seperti contoh, teknik budidaya tanaman pangan bahkan tanaman hortikultura dilakukan tanpa adanya proses penyiraman (hanya mengandalkan curah hujan). Hal ini yang menyebabkan, belum optimalnya produksi tanaman pangan dan hortikultura di wilayah Wamena dan sekitarnya, yang diakibatkan oleh adanya serangan hama dan penyakit. Sebagaimana, hasil penelitian Pumoko (2019) bahwa tingkat serangan hama dan penyakit pada tanaman sawi mencapai $72 \%$ serangan hama ulat grayak, yang menyebabkan kehilangan daun sawi tanpa pengendalian organisme pengganggu tanaman. Mengingat, sistem pertanian di Wilayah Wamena dan sekitar tergolong sistem pertanian organik. Untuk itu, perlunya kesadaran masyarakat akan pentingnya mengkonsumsi pangan yang sehat dan aman. Salah satu prinsip pertanian organik adalah mendaur ulang sisa-sisa hasil pertanian yang ada untuk dijadikan sumber pupuk maupun sebagai pestisida (Hersanti et al., 2013).

Salah satu komponen atau input dalam peningkatan produktivitas pertanian adalah pengendalian hama. Hama adalah organisme pengganggu tanaman yang dibudidayakan. Organisme hama sangat beragam, dari golongan serangga, burung sampai mamalia. Dari sekian banyak organisme itu, golongan hama yang terdiri atas banyak jenis atau spesies adalah golongan serangga. Insektisida atau pestisida pembasmi serangga hama yang berasal dari bahan kimia sintetis, selama ini telah dianggap juru selamat karena telah memberikan sumbangan yang nyata terhadap program peningkatan produksi pertanian yang sekaligus meningkatkan pendapatan petani. Setelah keberhasilan yang diperoleh, semakin lama semakin dirasakan bahwa penggunaan pestisida telah menimbulkan akibat sampingan yang merugikan bagi kelestarian ekosistem pertanian guna menunjang pembangunan pertanian yang berkelanjutan.

Saat ini telah meningkat dengan pesat pola pertanian organik mulai menjadi idola dalam dunia pertanian. Produk pertanian yang selama ini menggunakan pupuk kimia dan pestisida non-organik mulai tergantikan dengan produk pertanian organik yang memanfaatkan bahan alami, sebagai pupuk maupun pestisida. Penggunaan pestisida untuk mengendalikan hama dan penyakit sudah menjadi suatu kebiasaan petani dalam pengelolaan lahan pertaniannya. Namun, penggunaan pestisida yang kurang bijaksana dapat menimbulkan masalah kesehatan, pencemaran lingkungan, dan gangguan keseimbangan ekologis (Hersanti et al., 2013). Oleh karena itu, perhatian pada alternatif pengendalian yang lebih ramah lingkungan perlu semakin ditingkatkan.

Pestisida organik yang berasal dari tumbuhan disebut pula dengan pestisida nabati. Contoh tanaman yang dapat digunakan sebagai pestisida yaitu Tanaman pepaya (Carica papaya). Berdasarkan penelitian yang dilakukan oleh Konno dalam Julaily et al., (2013), getah pepaya mengandung kelompok enzim sistein protease seperti papain dan kimopapain. Getah pepaya juga menghasilkan senyawa-senyawa golongan alkaloid, terpenoid, flavonoid 
dan asam amino nonprotein yang sangat beracun bagi serangga pemakan tumbuhan. Adanya kandungan senyawa-senyawa kimia di dalam tanaman pepaya yang terkandung dapat mematikan organisme pengganggu. Berdasarkan penelitian yang dilakukan oleh Yenie et al., (2013) yaitu pembuatan pestisida organik menggunakan metode ekstraksi dari sampah daun pepaya dan umbi bawang putih menunjukkan bahwa semakin tinggi konsentrasi ekstrak daun pepaya dan umbi bawang putih semakin tinggi tingkat kematian hama uji, dimana konsentrasi yang paling banyak membunuh larva nyamuk pada konsentrasi larutan 3000 ppm dengan presentase kematian hewan uji sebesar $95 \%$ untuk ekstrak etanol dan $97,5 \%$ untuk ekstrak metanol.

Kandungan senyawa kimia yang terdapat pada bawang putih yaitu allixin, adenosin, ajoene, flavonoid, saponin, tuberholosida, scordinin. Dimana aliixin, saponin, dan flavonoid merupakan bahan kimia yang dapat difungsikan sebagai insektisida terutama dalam membasmi kutu rambut yang aman bagi kesehatan dan lingkungan (Sukma, 2016). Bawang putih adalah herbal semusim berumpun yang mempunyai ketinggian sekitar $60 \mathrm{~cm}$. Memiliki batang semu berwarna hijau dan bagian bawahnya bersiung-siung bergabung menjadi umbi besar berwarna putih (Khairani, 2014). Bawang putih memiliki kandungan berbagai zat yang menguntungkan bagi manusia, beberapa zat yang terkandung dalam bawang putih terbukti ampuh mengobati berbagai penyakit dan menjaga kesehatan tubuh (Trishadi, 2016). Selain bawang putih, cabai juga merupakan bahan dasar pestisida nabati yang dapat digunakan dalam membasmi hama pada tanaman.

Cabai atau lombok merupakan tanaman yang mudah ditanam di dataran rendah ataupun di dataran tinggi. Tanaman cabai banyak mengandung vitamin A dan vitamin $\mathrm{C}$ serta mengandung minyak atsiri capsaicin, yang menyebabkan rasa pedas dan memberikan kehangatan panas bila digunakan untuk rempah-rempah (bumbu dapur). Cabai dapat ditanam dengan mudah sehingga bisa dipakai untuk kebutuhan sehari-hari tanpa harus membelinya di pasar (Harpenas, 2010). Menurut Hendayana (2014) hama yang terkena atau memakan tanaman yang terkena semprotan air cabai akan mengering dengan membran sel rusak kehabisan cairan. Karena itulah cabai menjadi pestisida nabati yang ampuh mengendalikan kutu, tungau, ulat, sampai cacing perusak akar.

Beberapa tumbuhan diketahui memiliki kandungan zatzat kimia yang berpotensi untuk pengendalian hama pada tanaman (Dono et al., 2012). Pemanfaatan tumbuhan sebagai bahan aktif pestisida mulai banyak digunakan untuk pengendalian hama dan penyakit. Hal ini dikarenakan tumbuhan adalah sumber bahan kimia potensial yang dapat digunakan sebagai pestisida yang ramah lingkungan dan lebih aman secara kesehatan (Wiratno et al., 2014). Di Indonesia bahan pestisida nabati banyak tersedia di alam. Sebanyak 37.000 spesies flora telah diidentifikasi dan baru sekitar $1 \%$ yang telah dimanfaatkan (Djunaedy, 2009).

Pestisida nabati selain ramah lingkungan juga merupakan pestisida yang relatif aman dalam penggunaannya dan ekonomis. Pepaya merupakan tanaman yang memiliki potensi sebagai pestisida nabati untuk mengendalikan serangga hama. Papain yang terkandung alam daun pepaya bersifat meracun bagi ulat dan hama penghisap (Konno et al., 2004; Julaily, et al. 2013). Papain merupakan enzim proteolitik, yaitu enzim yang dapat mengurai dan memecah protein dan berpotensi sebagai pestisida (Robert \& Bryony, 2010). Namun demikian, penggunaan daun papaya sebagai insektisida nabati untuk mengendalikan hama, terutama kutu daun pada sayuran belum banyak dilakukan. Karena itu, informasi yang terkait dengan takaran ekstrak daun pepaya yang efektif untuk pengendalian hama kutu daun terung masih sangat terbatas.

Pembuatan bahan alami untuk pestisida dan obat-obat pertanian cukuplah mudah, namun mengingat keterbatasan SDM masyarakat sehingga hal ini menjadi kendala tersendiri dalam pengembangan sistem pertanian organik yang sudah ada. Untuk itu, pelaksanaan kegiatan pengabdian ini diharapkan dapat menjadi gerbang utama dalam meningkatkan kesadaran masyarakat terkait pemanfaatan bahan alami sebagai pestisida organik di bidang pertanian terutama untuk wilayah Wamena dan sekitarnya.

Pestisida organik atau pestisida nabati merupakan pestisida yang berasal dari bahan organik, yang berfungsi sebagai obat tanaman dalam melindungi tanaman dari serangan hama akibat dari aroma dan kandungan bahan alami yang tidak disukai oleh hama tanaman. Seperti yang juga dikemukakan oleh Grdisa \& Grsic, 2013 bahwa Pestisida nabati adalah pestisida yang bahan dasarnya berasal dari tumbuhan yang relatif mudah dibuat dengan kemampuan yang terbatas, karena pestisida nabati bersifat mudah terurai. Untuk itu, tujuan dari kegiatan pengabdian ini adalah untuk memberikan keterampilan kepada para petani di Desa Isaba Himan, Distrik Siepkosi, Kabupaten Jayawijaya terkait pembuatan pestisida nabati yang murah dan ramah lingkungan dalam meningkatkan produktivitas pertanian dengan cara sosialisasi dan memberikan pengetahuan tentang pestisida nabati kepada para petani di Desa Isaba Himan, Distrik Siepkosi, Kabupaten Jayawijaya.

\section{METODE PELAKSANAAN KEGIATAN}

Kegiatan Pengabdian ini dilaksanakan di Desa Isaba Himan, Distrik Siepkosi, Kabupaten Jayawijaya, Provinsi Papua pada Bulan April 2018 yang berlangsung selama \pm 
1 bulan bersamaan jalannya Program Kuliah Kerja Nyata (KKN) STIPER Petra Baliem Wamena Angkatan IX T.A. 2017/2018. Pelaksanaan pelatihan dan praktik pembuatan pestisida dilaksanakan di rumah Ketua Distrik Siepkosi, Kota Wamena, Kabupaten Jayawijaya. Peserta yang hadir pada pelatihan ini berjumlah 20 orang petani.

Adapun alat dan bahan yang digunakan adalah penumbuk/blender, penyaring/kain kasa, ember sebagai wadah penimpanan, dan botol semprot. Sedangkan, bahan yang digunakan adalah daun pepaya, bawang putih, bawang bombai, cabai, deterjen bubuk, kulit bawang merah, kunyit, dan serai.

\subsection{Tahapan dan Metode Pelaksanaan}

Kegiatan pengabdian ini dilakukan dengan beberapa tahap, yakni perizinan, demonstrasi pembuatan pestisida, praktik pembuatan pestisida nabati dan pendampingan pelatihan pembuatan pestisida nabati.

\section{- Perizinan}

Perizinan merupakan tahapan awal dalam kegiatan ini, yang bertujuan untuk menginformasikan kepada pemerintah dan atau kelompok masyarakat mengenai rencana pelaksanaan kegiatan pengabdian kepada masyarakat yang dimaksud. Kegiatan ini dilakukan dengan metode diskusi secara langsung dengan pemerintah distrik dan ketua kelompok tani.

- Persiapan Alat dan Bahan Pelatihan

Bahan dan alat pelatihan dipersiapkan adalah penumbuk/blender, penyaring/kain kasa, ember sebagai wadah penimpanan, dan botol semprot. Sedangkan, bahan yang digunakan adalah daun pepaya, bawang putih, cabai, deterjen bubuk, kulit bawang merah, kunyit, dan serai.

\section{- Demonstrasi Pembuatan Pestisida Nabati}

Kegiatan demonstrasi merupakan tahapan ketiga dalam kegiatan ini, setelah mendapatkan izin pelaksanaan dari pemerintah distrik dan ketua kelompok tani. Kegiatan ini dihadiri oleh sekertaris dan ketua distrik dan lokasinya di rumah ketua ketua Distrik. Kegiatan demonstrasi dilakukan untuk menjelaskan terkait konsep pembuatan pestisida nabati dari beberapa bahan yang mudah diperoleh dilingkungan sekitar, seperti daun papaya, bawang merah, cabai, bawang putih, kunyit, serai dan kulit bawang merah.

- Teori dan Praktik Pembuatan Pestisida Nabati

Pembuatan pestisida nabati dapat dilakukan secara sederhana dan secara laboratorium. Pembuatan pestisida nabati, yaitu dalam bentuk ekstrak secara sederhana (jangka pendek) dapat dilakukan oleh petani, dan penggunaannya biasanya dilakukan sesegera mungkin setelah pembuatan ekstrak. Pembuatan secara sederhana ini berorientasi kepada penerapan usaha tani berinput rendah.
Kegiatan praktik pembuatan pestisida dimulai dilakukan setelah penyampaian teori singkat dan penyebaran selebaran brosur terkait komposisi detail pestisida yang akan dibuat. Berikut adalah langkah pembuatan pestisida nabati dari beberapa bahan yang mudah diperoleh di lingkungan sekitar:

Daun Pepaya: Pestisida alami dari ekstrak daun pepaya memiliki beberapa manfaat, antara lain: dapat digunakan untuk mencegah hama seperti aphid, rayap, hama kecil, dan ulat bulu serta berbagai jenis serangga. Adapun cara membuatnya adalah sebagai berikut:

a) Haluskan (tumbuk atau blender) daun pepaya segar sebanyak 5 ikat (1 kantong plastik/kresek besar).

b) Kemudian rendam daun papaya yang sudah halus dalam 5 liter air dan tambahkan 2 sendok makan minyak tanah dan $5 \mathrm{sdm}$ detergen. Kemudian direndam semalaman.

c) Kemudian saringlah hasil perendaman dengan menggunakan kain halus

d) Setelah disaring, larutan sudah bisa digunakan/disemprotkan ke tanaman.

Bawang Putih, Bawang Bombai dan Cabai: Ekstrak bawang putih diketahui berguna untuk mengendalikan beberapa jenis organisme pengganggu tanaman (OPT), baik itu hama serangga, bakteri maupun jamur patogen. Sedangkan Cabai mengandung minyak atsiri, piperin dan piperidin yang berfungsi sebagai repellent dan mengganggu preferensi makan hama (Harysaksono et al. 2008). Adapun cara membuatnya adalah sebagai berikut:

a) Bawang Putih, Bawang Bombai dan Cabai digiling masing-masing sebanyak $1 \mathrm{~kg}$.

b) Tambahkan sedikit air,

c) Diamkan selama 1 jam.

d) Tambahkan $10 \mathrm{sdm}$ detergen, kemudian aduk sampai rata.

e) Diamkan selama 7-10 hari.

f) Bila ingin menggunakan campurkan lagi dengan air selanjutnya disemprotkan ke tanaman.

Kulit Bawang Merah: Pada konsentrasi tinggi, senyawa tersebut memiliki keistimewaan sebagai anti-feeden sehingga serangga tidak nafsu makan. Sedangkan pada konsentrasi rendah, akan menyebabkan terganggunya proses pencernaan dan merusak organ-organ pencernaan, yang mengakibatkan kematian pada hama serangga (Plantus, 2008). Selain itu, zat dan senyawa yang terdapat pada kulit bawang merah dapat memberikan kesuburan bagi tanaman sehingga dapat mempercepat tumbuhnya bunga dan buah pada tanaman. Adapun cara membuatnya adalah sebagai berikut:

a) Ambil kulit bawang merah terluar kemudian direndam dengan air.

b) Perendaman dilakukan semalam kemudian keesokan hari di larutan disaring dengan menggunakan kain halus 
c) Kemudian larutan disemprotkan semprotkan ke tanaman

Kunyit dan Serai: Rimpang kunyit dapat menjadi bahan pestisida nabati dan bahan penghambat nitrifikasi. Salah satu jenis tanaman yang menghasilkan senyawa metabolit sekunder dan dapat digunakan sebagai antimikroba dan fungisida alami adalah kunyit (Curcuma domestica $\mathrm{Val}$ ). Kunyit merupakan salah satu tanaman dari famili Zingiberaceae yang sudah lama dikenal oleh masyarakat Indonesia sebagai bahan baku obat tradisional (Sastrohamidjodjo, 2004). Kandungan utama kunyit adalah minyak atsiri dan kurkuminoid. Senyawa-senyawa yang terkandung dalam kunyit memiliki aktifitas biologis sebagai anti bakteri, antioksidan dan anti hepatotoksik (Rukmana, 1994). Adapun cara membuatnya adalah sebagai berikut:

a) Haluskan atau tumbuk rimpang kunyit sebanyak $1 \mathrm{~kg}$ dan serai sebanyak 10 ikat
a) Kemudian dicampurkan dalam sebuah ember/wadah
b) Kemudian tambahkan air sebanyak 5 - 10 Liter.
c) Kemudian disaring dengan menggunakan kain halus.
d) Selanjutnya, larutan hasil penyaringan sudah dapat disemprotkan ke tanaman

- Pendampingan Pelatihan Pembuatan Pestisida Nabati Kegiatan pendampingan ini dilakukan untuk dapat memberikan ruang kepada kelompok tani Dino Waga dalam berdiskusi sehingga kegiatan dalam pembuatan pestisida dapat terlaksana dengan mudah ketika kelompok tani mengalami kendala ataupun permasalahan dalam menghadapi serangan hama di lapangan.

\section{HASIL DAN PEMBAHASAN \\ Hasil Kegiatan Perizinan dengan Pemerintah Distrik serta Kelompok Tani}

Kegiatan sosialisasi dalam pelaksanaan kegiatan pengabdian masyarakat diawali dengan perizinan kepada pemerintah distrik serta Ketua Kelompok Tani Dino Waga. Kegiatan ini dilakukan dengan menginformasikan kepada pemerintah distrik mengenai tujuan dan rencana kegiatan pengabdian. Hasil dari kegiatan diskusi menunjukkan bahwa pemerintah Distrik Siepkosi mengapresiasi kegiatan pelatihan dan pendampingan ini. Hal ini dikarenakan, selama ini dengan sistem pertanian organik yang sudah lama diterapkan, petani belum pernah mengetahui adanya pemanfaatan pestisida nabati selain pestisida kimia sebagai salah satu racun bagi hama yang menyerang tanaman. Pemerintah distrik berharap seluruh masyarakat dapat mengikuti kegiatan tersebut untuk memperoleh ilmu dalam pembuatan pestisida nabati ini agar dapat dikembangkan di Distrik Siepkosi.

Setelah melakukan proses perizinan dengan pemerintah distrik dan ketua Kelompok Tani Dino Waga, tahapan selanjutnya adalah kegiatan demonstrasi atau sosialisasi awal dengan kelompok tani, yaitu penyampaian jadwal dan rencana kegiatan yang akan dilaksanakan. Hal tersebut bertujuan agar anggota Kelompok Tani Dino Waga dapat menyesuaikan waktu untuk dapat mengikuti praktik pembuatan Pestisida Nabati di Distrik Siepkosi, Wamena, Kabupaten Jayawijaya, Papua.

\section{Pelaksanaan Pelatihan Pembuatan Pestisida Nabati}

Pelaksanaan kegiatan pelatihan pembuatan pestisida nabati dihadiri oleh \pm 20 anggota kelompok tani Dino Waga, yang dimulai dengan persetujuan Ketua Kelompok Tani dengan melakukan perjanjian kerjasama pelaksanaan kegiatan pengabdian, dan pemilihan lokasi yang strategis serta mudah dijangkau oleh masyarakat dalam pelaksanaan kegiatan. Lokasi pelaksanaan adalah di halaman rumah ketua Distrik Siepkosi. Pelaksanaan kegiatan pelatihan ini dapat dilihat berikut ini (Gambar 1 dan 2). Proses sosialisasi dilakukan dengan bantuan penyebaran brosur, seperti pada gambar 3 dan 4 .

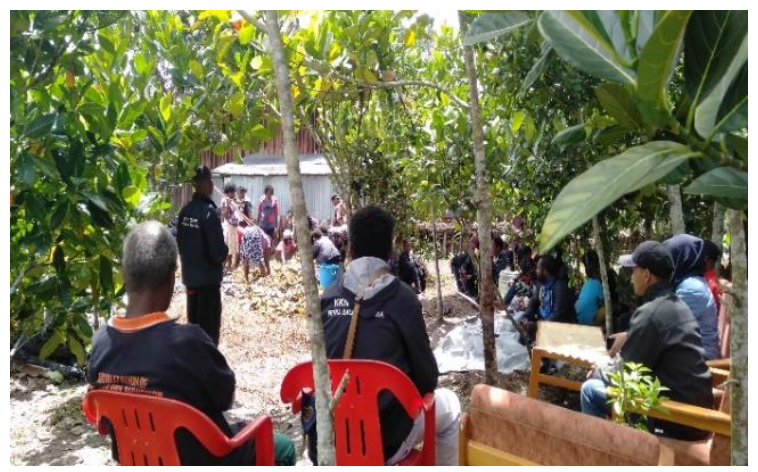

Gambar 1. Proses Pembukaan oleh Mahasiswa (Sumber: Pribadi, 2018)

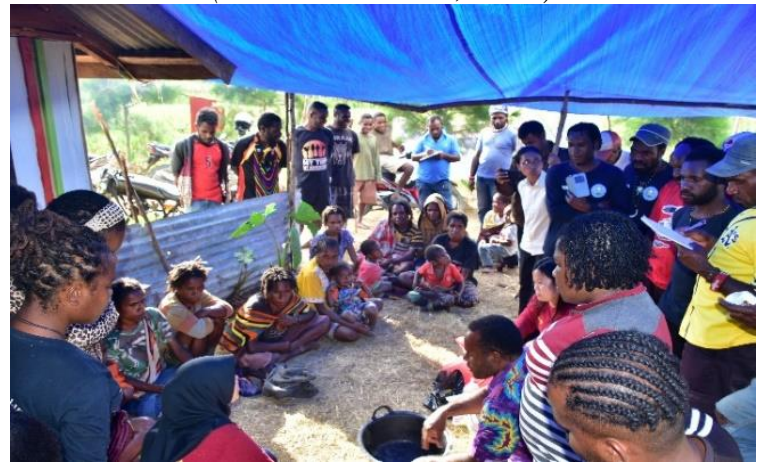

Gambar 2. Proses Sosialisasi. (Sumber: Pribadi, 2018) 

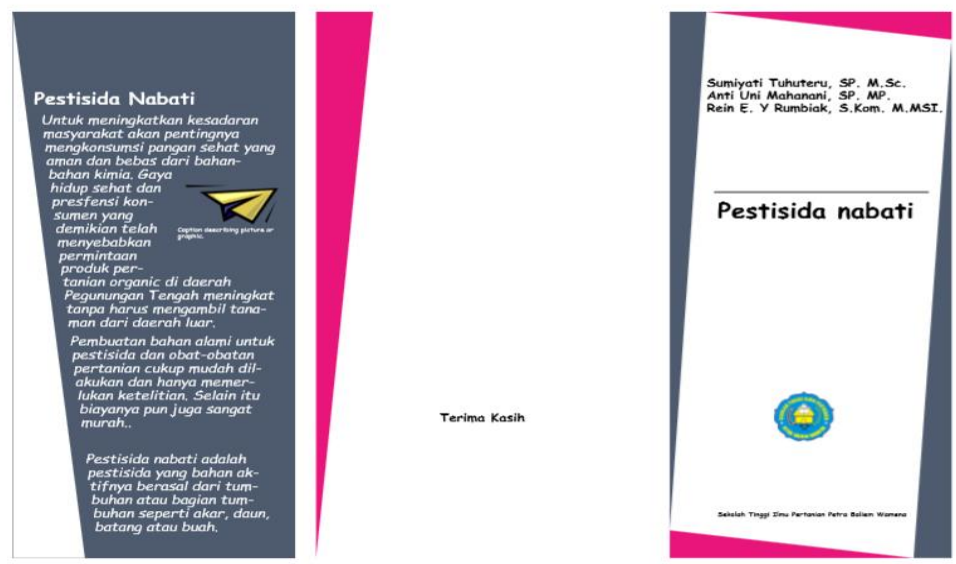

Gambar 3. Halaman Depan Brosur (Sumber: Pribadi, 2018)

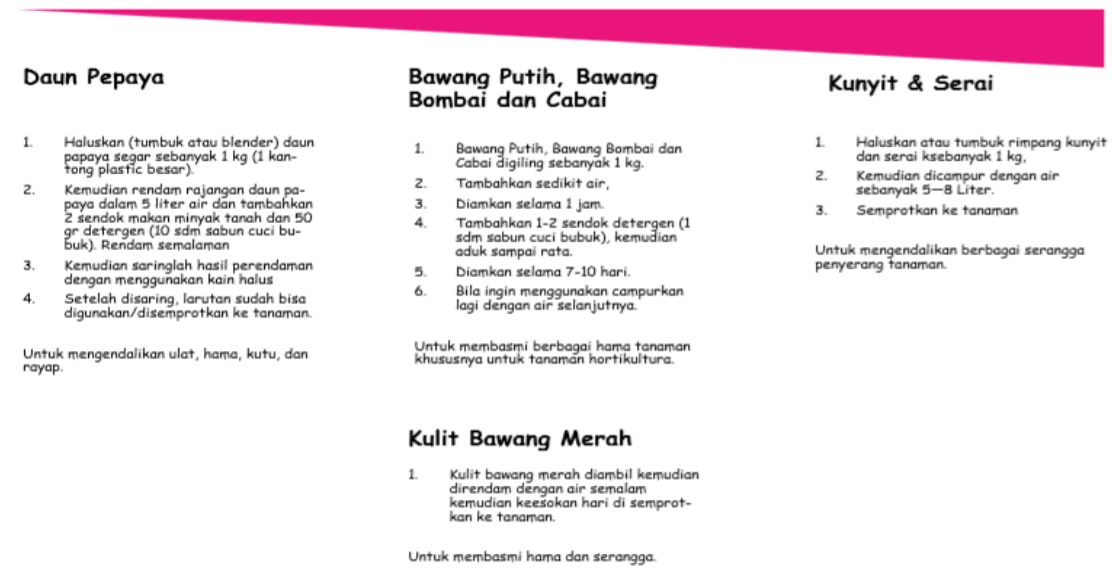

Gambar 4. Halaman Belakang Brosur (Sumber: Pribadi, 2018)

Hasil pengamatan dari kegiatan yang diselengarakan selama pelatihan menunjukkan bahwa petani mempunyai pengetahuan tentang tanaman-tanaman yang berpotensi sebagai pestisida alami, akan tetapi para petani masih kurang pengetahuan dalam memilih jenis tumbuhan dan organisme pengganggu tumbuhan (OPT) yang dapat dikendalikan. Selain itu, pembuatan pestisida memerlukan waktu, peralatan, dan terbatasnya ketersediaan tanaman yang diperlukan terbatas.

Kegiatan pembuatan pestisida Nabati diketahui bertujuan sebagai obat atau pestisida nabati bagi tanaman yang dibudidyakan petani di Distrik Siepkosi. Pestisida nabati yang dibuat diketahui berfungsi dalam mencegah serangan hama pada tanaman palawija yang dibudidayakan petani setempat. Dengan kata lain, hal ini bertujuan untuk membantu menyediakan obat bagi penggangu tanaman yang ditanam oleh petani di Distrik Siepkosi dan dapat dilakukan secara berkelanjutan.

Diketahui bahwa, pestisida nabati adalah pestisida yang berasal dari tumbuhan yang mengandung senyawasenyawa bioaktif seperti alkaloid, terperoid, fenolik, dan senyawa lainnya yang dapat menghambat atau mematikan hama atau penyebab penyakit (patogen). Metabolit sekunder dapat terkandung pada jaringan seperti sel parenkim pada daun, akar, bunga, biji atau kulit batang atau kayu, rimpang atau bahkan di seluruh bagian tumbuhan (Grainge \& Ahmed, 1987). Senyawa yang terkandung dalam tumbuh-tumbuhan dapat berpengaruh terhadap serangga hama melalui penghambat nafsu makan, reppelent (penolak), menghambat perkembangan, 
menurunkan reproduksi, pengaruh langsung sebagai racun, mencegah peletakan telur. Senyawa dalam tumbuhtumbuhan juga dapat menghambat pertumbuhan jamur, menghambat perkecambahan spora dan pembentukan spora (sporulasi) yang merupakan sumber guna penyebaran penyakit (Istifadah dan Dono, 2010).

Pestisida organik merupakan ramuan obat-obatan untuk mengendalikan hama dan penyakit tanaman yang dibuat dari bahanbahan alami. Bahan-bahan untuk membuat pestisida organik diambil dari tumbuhan-tumbuhan, hewan dan mikroorganisme. Karena dibuat dari bahanbahan yang terdapat di alam bebas, pestisida jenis ini lebih ramah lingkungan dan lebih aman bagi kesehatan manusia.

Bila dibandingkan dengan pestisida kimia, pestisida organik mempunyai beberapa kelebihan. Pertama, lebih ramah terhadap alam, karena sifat material organik mudah terurai menjadi bentuk lain. Sehingga dampak racunnya tidak menetap dalam waktu yang lama di alam bebas. Kedua, residu pestisida organik tidak bertahan lama pada tanaman, sehingga tanaman yang disemprot lebih aman untuk dikonsumsi. Ketiga, dilihat dari sisi ekonomi penggunaan pestisida organik memberikan nilai tambah pada produk yang dihasilkan. Produk pangan nonpestisida harganya lebih baik dibanding produk konvensional. Selain itu, pembuatan pestisida organik bisa dilakukan sendiri oleh petani sehingga menghemat pengeluaran biaya produksi. Keempat, penggunaan pestisida organik yang diintegrasikan dengan konsep pengendalian hama terpadu tidak akan menyebabkan resistensi pada hama.

Di Indonesia terdapat lebih dari 100 jenis tumbuhan yang mengandung bahan pestisida botani, beberapa diantaranya telah diketahui keefektifannya terhadap serangga hama ataupun penyakit. Tumbuhan yang berpotensi digunakan sebagai pengendali hama dan penyakit adalah tumbuhan yang biasanya jarang terserang hama dan penyakit, rasanya pahit atau berbau menyengat. Bagian tanaman yang dapat digunakan dapat berupa daun, ranting, biji dan, akar/rimpang, tergantung jenis tanamannya. Biasanya bagian yang bersifat paling beracun adalah biji (Istifadah dan Dono, 2010).

Dalam pelaksanaanya, ada banyak hal yang menjadi pertanyaan masyarakat yang hadir pada pelaksanaan kegiatan pelatihan tersebut, di antaranya adalah bagaimana cara mempraktekkan pemberian pestisida nabati tersebut, kapan pemberian yang tepat bagi tanaman, reaksi yang terjadi pada saat pengaplikasian pestisida nabati tersebut. Hal ini yang menjadi tantangan tersendiri bagi kami dalam meningkatkan pengetahuan petani terkait pemanfaatan pestisida nabati, yang merupakan salah satu teknologi alamiah dalam pertanian organik, yang belum diketahui oleh petani di Distrik Siepkosi, yang telah secara luas dikenal oleh masyarakat pada umumnya. Tantangan inilah yang kami jadikan peluang dalam pengembangan sistem pertanian organik yang telah lama diterapkan di Wilayah Dataran Tinggi Wamena, yang diketahui merupakan sentra pertanian organik di Timur Indonesia. Hal ini dikarenakan, pertanian organik yang dikenal oleh masyarakat Wamena adalah sistem budidaya yang meniadakan input apapun, selain pupuk kandang sapi maupun babi. Karena, masyarakat belum mengenal apa yang dimaksud dengan pupuk organik selain kotoran hewan.

Bagi masyarakat setempat istilah pupuk atau pestisida digunakan oleh bahan kimia yang diketahui dapat merusak lingkungan hidup terutama tanah. Selain itu, hal ini juga menjadi peluang bagi kami dalam mengembangankan dan meningkatkan kreatifitas masyarakat dalam memanfaatkan bahan-bahan yang ada di lingkungan sekitar yang memiliki nilai positif bagi kehidupan masyarakat, seperti penggunaan bahan-bahan dapur sebagai bahan dasar pembuatan pestisida. Hal ini merupakan solusi alternatif meningkatkan pengetahuan petani terkait pestisida nabati yang dapat digunakan, selain sebagai bahan dapur juga sebagai obat bagi tanaman, sehingga dapat meminimalisisr serangan hama pada tanaman yang dibudidayakan, mengingat sistem pertanian yang diterapkan adalah sistem pertanian organik, yang apabila tidak menggunakan obat-obatan bagi penggangu tanaman maka, tanaman akan mengalami penurunan produktivitas akibat serangan hama dan penyakit. Hal ini juga menjadi sebuah antusiasme kami dalam mengembangkan dan meningkatkan kemandirian pangan melalui pemanfaatan pestisida nabati.

Dari hasil tanya jawab pengetahuan petani tentang pestisida nabati masih rendah dan dari paparan jenis-jenis tanaman dan cara pembuatan pestisida, pada umumnya para petani mengenal jenis-jenis tanaman yang dapat digunakan sebagai pestisida nabati, akan tetapi cara pembuatannya, aplikasi dan kegunaannya belum banyak diketahui. Pemaparan tentang pestisida jenis ini disertai diskusi menghabiskan waktu, sementara praktik pembuatan pestisida nabati dilaksanakan selama 6 jam. Pestisida nabati yang dibuat sebagian digunakan untuk aplikasi pada demplot keesokan harinya.

Dalam praktiknya, terlihat jelas pembuatan pestisida nabati merupakan hal baru bagi anggota kelompok tani Dino Waga Distrik Siepkosi. Kendala tersebut dikarenakan kurangnya sumber informasi dan keterbatasan akses informasi serta minimnya sumber daya manusia yang didukung oleh lambatnya teknologi untuk diterima di wilayah ini, sehingga mengakibatkan banyak masyarakat yang tidak mengerti konsep pertanian organik sesungguhnya yang sudah diketahui masyarakat luas. Namun, antusias masyarakat mampu membuat kami merasa dibutuhkan. 
Faktor-faktor yang mendukung keberhasilan pelatihan ini adalah ketersedian beberapa tumbuhan yang dapat digunakan sebagai pestisida nabati, keinginan dan semangat petani untuk lebih mengetahui pengendalian hama dan patogen tanaman yang ramah lingkungan.

\section{Kendala yang Dihadapi}

Kendala yang dihadapi pada saat pelaksanaan kegiatan pelatihan ini adalah minimnya ilmu pengetahuan yang dimiliki masyarakat sehingga dalam pelaksanaannya membutuhkan waktu terkait penjelasan konsep pestisida nabati dalam dunia pertanian, terutama dalam proses pembuatan pestisida nabati ini. Hal ini dikarenakan, rendahnya tingkat pendidikan masyarakat setempat yang diketahui sebagian besar tidak menduduki pendidikan formal. Minimnya pengetahuan yang dimiliki berpengaruh pada tingkat kemampuan dalam memahami sesuatu. Untuk itu, memerlukan waktu bagi kami dalam menjelaskan dan mempraktekkannya, bahkan dengan bantuan anggota kami sebagai penerjemah bahasa.

Faktor-faktor yang menghambat dalam program pelatihan ini adalah belum terkoordinasinya kelompok tani yang menggunakan pestisida alami ketersediaan bahan nabati masih kurang walaupun jenis tanaman yang berpotensi sebagai pestisida nabati serta cukup banyak. Di samping itu, belum banyak petani yang mengenal tentang penggunaan mikroba sebagai pestisida.

\section{Dampak dan Upaya Keberlanjutan Kegiatan}

Pelatihan selama dua hari membangkitkan ketertarikan beberapa petani untuk meningkatkan keterampilan dalam membuat pestisida nabati. Hasil ini menunjukkan bahwa petani peserta pelatihan tertarik untuk menggunakan pestisda alami untuk mengendalikan hama dan penyakit tanaman. Adapun dampak dan upaya keberlanjutan dari pelaksanaan kegiatan pelatihan pembuatan pestisida nabati ini adalah penerapan penggunaan pestisida nabati sebagai pestisida nabati mulai digunakan pada saat proses budidaya tanaman dilakukan. Selain itu, upaya keberlanjutan yang diperoleh dari pelaksanaan pelatihan ini adalah peningkatan pola tanam dengan metode pertanian organik yang baik dan benar, penggunaan pupuk organik dengan dosis yang tepat, dan pengguanaan pestisida nabati yang baik dan benar. Hal ini bertujuan untuk meningkatkan produktivitas tanaman yang dibudiayakan petani.

\section{SIMPULAN}

Kegiatan pengabdian kepada masyarakat melalui kegiatan KKN-PPM ini memberikan dampak positif dan pembelajaran yang baik bagi kami sehingga masyarakat di Distrik Siepkosi dapat mengembangkan pengetahuan terkait pestisida nabati guna membantu meningkatkan produktivitas tanaman melalui penerapan penggunaan pestisida nabati dalam budidaya tanaman yang bahan- bahannya mudah diperoleh, sehingga masyarakat dapat meningkatkan sistem pertanian organik yang telah ada dengan mengembangkan penggunaan pestisida nabati yang telah mereka ketahui. Kegiatan pengabdian masyarakat ini masih perlu dan terus dilakukan guna meningkatkan pengetahuan bagi mahasiswa, masyarakat, dan seluruh petani untuk terus meningkatkan kreasi, kreativitas, dan pengetahuan untuk menciptakan masyarakat yang mandiri serta berdaya saing.

\section{UCAPAN TERIMA KASIH}

Penulis mengucapkan terima kasih kepada Lembaga Penelitian dan Pengabdian Masyarakat Sekolah Tinggi Ilmu Pertanian Petra Baliem Wamena yang telah memfasilitasi kebutuhan dan kepentingan pengabdian ini, sehingga penulis dapat melaksanakan kegiatan pengabdian masyarakat ini melalui pelaksanaan kegiatan KKN-PPM di Distrik Siepkosi, Kabupaten Jayawijaya, Papua.

\section{DAFTAR PUSTAKA}

Djunaedy, A. (2009). Biopestisida sebagai pengendali organisme pengganggu tanaman (OPT) yang ramah lingkungan. Embryo, 6(1), 88-95.

Dono, D., Natawigena, W. D., \& Majid, M. G. (2012). Bioactivity of methanolic seed extract of Barringtonia asiatica L. (Kurz) (Lecythidaceae) on biological characters of Spodoptera litura (Fabricius) (Lepidoptera: Noctuidae). Int Res J Agric Sci Soil Sci, 2, 469-475.

Grainge, M. and S. Ahmed. (1987). Handbook of Plants with Pest-Control Properties. A WileyInterscience Publ., New York. 470 pp.

Grdiša, M., \& Gršić, K. (2013). Botanical insecticides in plant protection. Agriculturae Conspectus Scientificus, 78(2), 85-93.

Harpenas, (2010). Budidaya Cabai Unggul. Penebar Swadaya. Jakarta.

Harysaksono S, Purwanti EW, Sule S. (2008). Pestisida Nabati. Malang: Sekolah Tinggi penyuluhan Pertanian. Kalie BM.

Hendayana, D. (2014). Mengenal Tanaman Bahan Pestisida Nabati. Sumber: www.academia.edu/ 5533755/Mengenal-tanaman-bahan-pestisidanabati. Diakses 28 Januari 2019.

Hersanti, Santosa E., dan Dono D., (2013). Pelatihan Pembuatan Pestisida Alami untuk Mengendalikan Hama dan Penyakit Tanaman Padi di Desa Tenjolaya dan Desa Sukamelang, Kecamatan Kasomalang, Kabupaten Subang. Dharmakarya: Jurnal Aplikasi Ipteks untuk Masyarakat 2 (2) : 139 -145 .

Istifadah N. dan Dono D., (2010). Eksplorasi dan Perkembangbiakan Masal Musuh Alami Kutu Kebul (Bemisia tabaci Genn.) dari Beberapa Sentra Produksi Tanaman Sayuran di Jawa Barat. 
Monograf. Departemen Koperasi. Inspektorat Jenderal.

Julaily, N., \& Mukarlina, T. R. S. (2013). Pengendalian hama pada tanaman Sawi (Brassica juncea L.) menggunakan ekstrak daun Pepaya (Carica papaya L.). Protobiont, 2(3).

Khairani, A. (2014). Bawang Putih Raja Tanaman Kedokteran. Surabaya: Alfasyam Publishing.

Konno, K., Hirayama, C., Nakamura, M., Tateishi, K., Tamura, Y., Hattori, M., \& Kohno, K. (2004). Papain protects papaya trees from herbivorous insects: role of cysteine proteases in latex. The Plant Journal, 37(3), 370-378.

Munarso, J., Miskiyah, Broto, W. (2006). Studi Kandungan Residu Pestisida pada Kubis, Tomat, dan Wortel di Malang dan Cianjur. Bogor: Buletin Teknologi Pascapanen Pertanian

Ningrum P. T., Pujiati R. S., Ellyke dan M. A. Dewi, (2014). Rendaman Daun Pepaya (Carica papaya) sebagai Pestisida Nabati Untuk Pengendalian Hama Ulat Grayak (Spodoptera litura) pada Tanaman Cabai. Prosiding Seminar Nasional Current Challenges in Drug Use and Development Tantangan Terkini Perkembangan Obat dan Aplikasi Klinis.

Pumoko P. 2019. Pengaruh Beberapa Pestisida organik terhadap Serangan Hama Ulat Grayak (Spodoptera litura F.) pada Pertumbuhan Tanaman Sawi. Skripsi. Program Studi Agroteknologi, Sekolah Tinggi Ilmu Pertanian Petra Baliem Wamena. (Tidak dipublikasikan)

Rukmana, R.. (1994). "Kunyit”. Yogyakarta: Kanisius.

Plantus. 2008. Atasi Hama Belalang secara Organik. http://anekaplanta.wordpress.com/2008/03/02/atas i-hama-belalang-secaraorganik/.html. (Diakses: 4 Januari 2019)

Robert L. Harrison and Bryony C. Bonning. (2010). Proteases as Insecticidal Agents. Toxins (Basel). 2(5): 935-953.

Sastrohamidjojo H. (2004). Kimia minyak atsiri. Yogyakarta : Gajah Mada University press.

Sukma, D. (2016). Sehat Tanpa Obat Dengan Bawang Merah Dan Bawang Putih. Yogyakarta: Rapha Publishing.

Trishadi, R. (2016). Pestisida Nabati Ramah Lingkungan Untuk Mengendalikan Hama Dan Penyakit Tanaman. Probolinggo: Dinas Perkebunan Dan Perhutanan.

Wiratno, Siswanto dan IM Trisawa. (2014). Pestisida Nabati: Perkembangan, Formulasi, dan Percepatan Pemanfaatannya. Jurnal badan Penelitian dan Pengambangan pertanian.

Yenie, E., , S., Kalvin, A., Irfhan, M. (2013). "Pembuatan Pestisida Organik Menggunakan Metode Ekstraksi dari Sampah Daun Pepaya”. Teknik Lingkungan. 10(1): 46-59. 